\title{
Effects of Participating in Mentoring Activities for Self Leadership and Super Leadership Development in University Students
}

\author{
Lee, Suk Yeol and Hur Young Ju \\ General Education, Namseoul University \\ edupro@hanmail.net,youngju@nsu.ac.kr
}

\begin{abstract}
When university students discover who they are, and are able to live independent college life, they are able to find the confidence to take responsibility for their lives. Placing the focus on how university years are crucial for developing self-leadership, this study, as a method of cultivating self leadership and super leadership, aims to analyze the differences in the inclusion of mentoring provided by senior students in the school curriculum for developing freshmen's self leadership and super leadership. Building on this study, if existing leadership courses and senior-junior mentoring activities are parallel, self-leadership and super leadership of university students could be improved more effectively.
\end{abstract}

Keywords: senior-junior mentoring, self leadership, super leadership, university student

\section{Research Necessity}

As the life cycle of knowledge and information speeds up exponentially in the current knowledge based society, there is a need to go beyond simply 'knowing a lot' and move towards the importance of creative and flexible thinking. This is due to the increasing need for individuals to possess skills to autonomously and actively explore, acquire, and evaluate information for solutions to problems, and to actualize solutions and goals $[1,2]$. Modern society emphatically demands individuals to have the skills to independently explore, acquire, and evaluate information for solutions to problems rather than commanded and instruction-led problem solving. In response to these societal requirements and demands, many universities are interested in cultivating self leadership [3-5]. Self leadership is defined as self-goal setting, motivating oneself to create desired behavioral changes to influence and bear positive outcomes through a fundamental system of self-control [6-8].

Recently, as the sense of community is emphasized, there is increased interest in super leadership, the ability to encourage mutual growth in all members in a community and to prepare for the future [9]. Super leadership refers to the ability to promote self leadership of not only themselves but of others so they are able to make decisions, take action and take responsibility for their actions within the given objectives of the organization [10]. This means that university students should use self leadership as training and a springboard towards super leadership. However, current research on the leadership of university students mainly focuses on self leadership on the level of the individual. This study aims to analyze any differences present in the self leadership and super leadership of freshmen with leadership courses and senior-junior mentoring participation. 


\section{Theoretical Background}

\subsection{The Concept of Self Leadership and Super Leadership}

Self leadership is controlling one's own actions and thoughts in order to achieve individually set goals. In other words, self leadership is searching for actions that will lead to self motivation, and the ability to change one's thought to have a positive and constructive mind for work [11]. It is defined as having influence over oneself, and it is the foundation of self leadership, super leadership, servant leadership and emotional leadership. In addition, super leadership is creating leaders out of members who can judge and act independently and take responsibility for the subsequent outcomes and results [12]. In contrast to traditional leaders who command and directly present goals, information and solutions, super leaders promote internal motivation, encourage selfreinforcement, self goal-setting, establishing strategies, self-observation in the process of application, self evaluation, and self-expectations of the members by implementing strategies. Spanning all eras, great leadership maintains leadership without using the official position, and excellent leaders not only lead the people around them to discover and develop their own abilities but also allow them to commit and be dedicated to the organizations they belong to [13].

\subsection{Factors Influencing Self Leadership and Super Leadership}

There are several studies with self and super leadership as dependent variables to extract the influencing factors. Kazen(1999), with adults in the USA as research targets, inserted gender, stress, family satisfaction, social support, leadership experience, material possessions, race, age, level of education, marital status, duration of marriage, children, number of children, place of residence where they grew up, current place of residence, position, whether they had received leadership training, whether they received any subsidy, and the place of employment to extract the influencing factors on self leadership [14]. Kahn(2000) researched self leadership in light of the age, work experience, and work-related training of professionals in for-profit organizations and revealed strategies of self leadership [15]. Kim Ahn $\mathrm{Na}(2003)$ researched university students according to gender, socioeconomic status, educational aspirations and other individual variables, university related variables, educational variables, and other university environment related factors such as students and on-campus activities, and provided guidance for leadership development for universities as institutions of higher learning [16].

\subsection{The Status of Self Leadership \& Super Leadership Training in Universities}

Current university leadership classes are mainly conducted through the department of general education, and according to the philosophy the school held regarding leadership education, some classes were held simply through the department of general education, whereas some classes were offered systematically at a separate center and institutions established for leadership. In addition, leadership classes are generally not specified as a requirement to graduation but as elective subjects. According to Kim Min Kyung(2007), some universities have the goal to offer more opportunities of leadership education by creating leadership classes for the entire school. Methods of teaching were comprised of lectures, team debate and discussion, presentations, team assignments, special lectures and experiential learning. Smaller classes were comprised of approximately 10 students, larger classes were comprised of approximately 100 students, and larger classes would be divided up into smaller groups. Assignments were reports on experiential learning, researching on a selected leader, writing book reports on leadership books. Course contents were about understanding the concept of leadership, self awareness and understanding, understanding a leader, and classes are focused on a leader from a different field each week. Leadership courses were conducted differently in each school, a 
few schools were developing the leadership of every student, and a few schools were developing leadership in only a select number of students [17].

\section{Research Methodology and Contents}

\subsection{Research Target Audience and Research Model}

The research subjects for this study were two groups of freshmen students attending University $\mathrm{N}$ and enrolled in the 'University Life and Leadership' course during semester one, 2015. There were a total of 116 students: 44 male students and 72 female students. The first group (composed of 74 students) was the control group where students only participated in the leadership course, and the second group (composed of 42 students) was the experimental group that participated in the senior-junior mentoring session in addition to the leadership course. Detailed characteristics of the research subjects are presented in Table 1.

Table 1. General Characteristics of the Control and Experiment Group

\begin{tabular}{c|c|c|c|c|c|c|c}
\hline & \multicolumn{3}{|c|}{ Gender } & \multicolumn{4}{c}{ Grades } \\
\cline { 2 - 8 } & Male & Female & Total & A & B & C \& below & Total \\
\hline Control & $\begin{array}{c}33 \\
(44.6)\end{array}$ & $\begin{array}{c}41 \\
(55.4)\end{array}$ & $\begin{array}{c}74 \\
(100.0)\end{array}$ & $\begin{array}{c}16 \\
(21.6)\end{array}$ & $\begin{array}{c}20 \\
(27.0)\end{array}$ & $\begin{array}{c}38 \\
(51.4)\end{array}$ & $\begin{array}{c}74 \\
(100.0)\end{array}$ \\
\hline Experiment & $\begin{array}{c}11 \\
(26.2)\end{array}$ & $\begin{array}{c}31 \\
(73.8)\end{array}$ & $\begin{array}{c}44 \\
(100.0)\end{array}$ & $\begin{array}{c}15 \\
(35.7)\end{array}$ & $\begin{array}{c}19 \\
(45.2)\end{array}$ & $\begin{array}{c}8 \\
(19.0)\end{array}$ & $\begin{array}{c}42 \\
(100.0)\end{array}$ \\
\hline
\end{tabular}

The course content of the leadership courses offered covered understanding leadership, understanding oneself and understanding university study. The course was delivered in the form of lectures, group discussion and debates, student presentations, group assignments and special lectures. The two streams of classes were taught by the same lecturer to ensure the instructor factor was controlled. The experimental group was provided with bi-weekly mentoring sessions ( 8 sessions total) with a third year senior of the same major. The contents of the mentoring sessions were about adjusting to university life (registering for classes, course information, lecturer information, school facilities information etc.), academic learning related information (time management skills, study skills, test preparation strategies etc.), career and employment related information (preparation strategies after graduation etc.), among others. There was no set curriculum for mentoring; it was simply up to the questions the mentee asked the mentor. The pre-test was conducted in the first week of March 2015, before admissions, and the post-test was conducted in the second week of June. The design of this study is presented in [Diagram $1]$. 


\begin{tabular}{|c|c|c|}
\hline & Covariate Variable & \\
\hline & $\begin{array}{c}\text { Self and super } \\
\text { leadership before and } \\
\text { after test results, Grades } \\
\text { for first freshmen } \\
\text { semester }\end{array}$ & \\
\hline Independent Variable & $\rightarrow$ & Dependent Variable \\
\hline \multirow{3}{*}{ Presence/Absence of mentoring } & \multirow{3}{*}{$\rightarrow$} & Self Leadership \\
\hline & & $\mathrm{X}$ \\
\hline & & Super Leadership \\
\hline
\end{tabular}

\section{Diagram 1. Research Model}

\subsection{Research Method and Tools}

3.2.1. Self Leadership Evaluation Tools: This study used a 23 question ( 5 point scale) self leadership diagnostic tool developed by No Youn Shin and Jeong Cheol Young (2013) [18]. To perform a factor analysis for the validity of the results, a principal component analysis was applied to the questionnaire results. Varimax rotation was implemented among orthogonal rotation methods for factor rotation. The results of Bartlett's test for sphericity show the approximate chi-square value to be $1218.202(\mathrm{df}=253$, $\mathrm{p}=.000)$, the standard sampling adequacy KMO value was $.860(\mathrm{p}=.000)$. As such, the factor analysis was considered suitable. Components with eigenvalues equal or greater than one were selected, leaving five components. 6 principal components can explain $65.72 \%$ of the total variation. The results of the rotated matrix components and reliability are presented in Table 2, and the sub-factors of self leadership have been renamed based on the test question (see Table 3).

Table 2. Factor Analysis Results and Reliability of Self Leadership Tests

\begin{tabular}{c|c|c|c}
\hline Question & Detailed Factor & Subfactor & Reliability \\
\cline { 1 - 2 } $10,14,15,16$ & Goal Setting & \multirow{2}{*}{ Leading Self-behavior } & .808 \\
\cline { 1 - 2 } 11,12 & Self-observation & & \\
\cline { 1 - 2 } $6,7,8,9$ & Self-awareness & & \multirow{2}{*}{ Managing Self-thought } \\
\cline { 1 - 2 } $4,5,13$ & $\begin{array}{c}\text { Imagination of Future } \\
\text { Success }\end{array}$ & & \\
\cline { 1 - 2 } $3,18,19,20,21$ & Self-efficacy & & .898 \\
\hline Total & & &
\end{tabular}


Table 3. Conceptual Definition of Factors that Comprise Self Leadership

\begin{tabular}{|l|l|l|}
\hline Category & Sub-category & Concept \\
\hline \multirow{4}{*}{$\begin{array}{l}\text { Leading } \\
\text { Beh- }\end{array}$} & Goal Setting & $\begin{array}{l}\text { The ability to target and examine specific details and techniques to } \\
\text { specific goals, and the ability to utilize and concentrate available } \\
\text { resources to achieve one's goal. }\end{array}$ \\
\cline { 2 - 4 } & $\begin{array}{l}\text { Self- } \\
\text { Observation }\end{array}$ & $\begin{array}{l}\text { Gathering and collecting relevant information on one's detailed } \\
\text { behavior and actions to achieve their goal, and the ability to } \\
\text { implement preventative measures to control past inefficient } \\
\text { behavior. }\end{array}$ \\
\hline \multirow{5}{*}{$\begin{array}{l}\text { Managing } \\
\text { Self- } \\
\text { thought }\end{array}$} & $\begin{array}{l}\text { Self- } \\
\text { Amagination } \\
\text { Of Future } \\
\text { Success }\end{array}$ & $\begin{array}{l}\text { The ability to explore and discover one's fundamental value, } \\
\text { discover the orientation of one's life, to discover and understand } \\
\text { one's core strengths and weaknesses in the process of observation, } \\
\text { and being able to recognize these abilities. }\end{array}$ \\
\cline { 2 - 4 } & $\begin{array}{l}\text { The ability to imagine and visualize the completion of a planned } \\
\text { project (the process as well its completion), the ability to overcome } \\
\text { challenging situations, the ability to motivate by having confidence } \\
\text { and certainty of success. }\end{array}$ \\
\cline { 2 - 4 } & $\begin{array}{l}\text { The ability to successfully carry out the task regardless of } \\
\text { sircumstances encountered by heightening concentration and } \\
\text { persistence to strengthen a sense of purpose with the confidence in } \\
\text { one's abilities. }\end{array}$ \\
\hline
\end{tabular}

3.2.2. Super Leadership Evaluation Tool: This study used a 19 question (5 point scale) super leadership diagnostic tool developed by No Youn Shin and Jeong Cheol Young (2013) [13]. As validity and reliability is based on the measured results, a Principal Component Analysis was applied to the 19 questions for factor analysis. Varimax rotation was implemented among orthogonal rotation methods for factor rotation. The results of Bartlett's test for sphericity show the approximate chi-square value to be 793.241( $\mathrm{df}=171$, $\mathrm{p}=.000)$, the standard sampling adequacy KMO value was $.830(\mathrm{p}=.000)$. As such, the factor analysis was considered suitable. Components with eigenvalues equal or greater than one were selected, leaving five components, and the five principal components can explain $61.65 \%$ of the total variation. The results of the rotated matrix components and reliability are presented in Table 4, and the sub-factors of super leadership have been renamed based on the test question (see Table 5).

Table 4. Factor Analysis Results and Reliability of Super Leadership Tests

\begin{tabular}{|c|c|c|c|}
\hline Question & Detailed Factor & Subfactor & $\begin{array}{l}\text { Reliability } \\
\text { Factor }\end{array}$ \\
\hline $5,6,7,16$ & Communication & \multirow{3}{*}{ Driving Action } & \multirow{3}{*}{.797} \\
\hline $1,2,3$ & $\begin{array}{l}\text { Interpersonal } \\
\text { Relationships }\end{array}$ & & \\
\hline $8,10,11,12,14$ & Motivation & & \\
\hline $13,15,17,18,19$ & Insight & \multirow{2}{*}{ Inspiring Challenge } & \multirow{2}{*}{.782} \\
\hline 4,9 & Pursuing Excellence & & \\
\hline Total & & & .863 \\
\hline
\end{tabular}


Table 5. Conceptual Definition of Factors that Comprise Super Leadership

\begin{tabular}{|c|c|c|}
\hline Category & Subcategory & Concept \\
\hline \multirow{3}{*}{$\begin{array}{l}\text { Driving } \\
\text { Action }\end{array}$} & Communication & $\begin{array}{l}\text { The ability to effectively communicate one's thoughts and opinions } \\
\text { taking into consideration the perspective and emotions of others, } \\
\text { and furthermore the ability to persuade and encourage others to } \\
\text { change their behavior for the collective goals. }\end{array}$ \\
\hline & $\begin{array}{l}\text { Interpersonal } \\
\text { Relations) }\end{array}$ & $\begin{array}{l}\text { The ability to effectively control conflict with sensitivity and with } \\
\text { understanding oriented towards the others with the ability to } \\
\text { mediate based on the understanding of others and their expectations } \\
\text { and demands. }\end{array}$ \\
\hline & Motivation & $\begin{array}{l}\text { The ability to constantly develop oneself and to not settle for the } \\
\text { present to become an exceptional model self-leader, and the ability } \\
\text { to recognize the potential of others, emit positive energy and raise } \\
\text { motivation to achieve goals. }\end{array}$ \\
\hline \multirow{2}{*}{$\begin{array}{l}\text { Inspiring } \\
\text { Challenge }\end{array}$} & Insight & $\begin{array}{l}\text { The ability to visualize a solution to a problem combining interest } \\
\text { and inquiry in a variety of areas with one's area of expertise. Also, } \\
\text { concerning the ability to influence others, the ability to provide } \\
\text { instruction and help others and provide effective solutions with a } \\
\text { comprehensive understanding of the other person's characteristics } \\
\text { and context. }\end{array}$ \\
\hline & $\begin{array}{l}\text { Pursuing } \\
\text { Excellence }\end{array}$ & $\begin{array}{l}\text { The ability to encourage and support, establish high goal } \\
\text { expectations, giving others a constant sense of purpose and } \\
\text { motivation, reminding them of the need to achieve the goal and its } \\
\text { values. Also, an interest in working well and the ability to inspire } \\
\text { the desire to reach for the highest standards. }\end{array}$ \\
\hline
\end{tabular}

\subsection{Analysis Method}

Whether the presence of the independent variable of the senior-junior mentoring activity participation made a difference for the dependent variable of self leadership and super leadership was analyzed (See Table 6 for correlation analysis results).

Table 6. Correlation between Exogenous Variables, Initial Test Results and Dependent Variables

\begin{tabular}{|c|c|c|c|c|c|c|c|}
\hline & & \multirow[b]{2}{*}{ Gender } & \multirow[b]{2}{*}{ Grade } & \multicolumn{2}{|c|}{ Self Leadership } & \multicolumn{2}{|c|}{ Super Leadership } \\
\hline & & & & $\begin{array}{l}\text { Result } \\
\text { Before }\end{array}$ & $\begin{array}{c}\text { Result } \\
\text { After }\end{array}$ & $\begin{array}{l}\text { Result } \\
\text { Before }\end{array}$ & $\begin{array}{l}\text { Result } \\
\text { After }\end{array}$ \\
\hline \multicolumn{2}{|c|}{ Gender } & 1 & & & & & \\
\hline \multicolumn{2}{|c|}{ Grade } & -1.39 & 1 & & & & \\
\hline \multirow{2}{*}{$\begin{array}{c}\text { Self } \\
\text { Leadership }\end{array}$} & Before & .122 & $-2.23 *$ & 1 & & & \\
\hline & After & .145 & $-3.36 * * *$ & $.628 * * *$ & 1 & & \\
\hline \multirow{2}{*}{$\begin{array}{c}\text { Super } \\
\text { Leadership }\end{array}$} & Before & -.007 & -.061 & $.509 * * *$ & $.378 * * *$ & 1 & \\
\hline & After & .133 & $-.200 *$ & $.499 * * *$ & .781 *** & $.637 * * *$ & 1 \\
\hline
\end{tabular}

As the final grades and pre-test scores of self-leadership and super leadership show a significant correlation, by applying the analysis of covariance (ANCOVA), which sets final grades and pre-test scores of self-leadership and super leadership as the covariate variable, the two groups were statistically homogenous. Also, as the dependent variables of self-leadership and super leadership post-test scores had a significant correlation, a 
multivariate analysis of covariance (MANCOVA) was implemented. The Korean version of SPSS (ver. 18.0) for WINDOWS was used for statistical analysis.

\section{Research Results}

Examining the multivariate analysis result of the presence of mentoring participation, the effect that the independent variable of senior-junior mentoring has on the dependent variable of first semester freshmen's self leadership and super leadership differs. The independent variable of senior-junior mentoring is shown to have a significant effect in improving the dependent variable of freshmen's first semester self leadership and super leadership (See Table 7). University freshmen students enrolled in the course 'University Life and Leadership' during semester one who received mentoring from a senior improved their self leadership and super leadership more than students who had participated in the course only. These results applied to self leadership's 'Leading Self-behavior' and 'Managing Self-thought' and super leadership's 'Driving Action', yet there was no difference in super leadership's sub factor 'Inspiring Challenge'.

\section{Table 7. Difference in Self Leadership and Super Leadership Development With/Without Senior-Junior Mentoring Participation}

\begin{tabular}{|c|c|c|c|c|c|c|c|c|c|}
\hline \multirow{2}{*}{\multicolumn{4}{|c|}{ Category }} & \multicolumn{3}{|c|}{ Independent Variable(Mentoring) } & \multirow{3}{*}{$\begin{array}{c}\text { Modifie } \\
\mathrm{d} \\
\mathrm{R}^{2} \\
\\
29.560\end{array}$} & \multirow{3}{*}{$\begin{array}{c}\mathrm{F} \\
91.69^{* * *}\end{array}$} & \multirow{3}{*}{$\begin{array}{c}\eta^{2} \\
.452\end{array}$} \\
\hline & & & & \multirow{2}{*}{$\begin{array}{c}\text { Control } \\
\text { Group } \\
\text { (Absent) } \\
\mathrm{N}=74 \\
2.14 \\
(.67) \\
\end{array}$} & \multirow{2}{*}{ 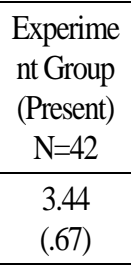 } & \multirow{2}{*}{$\begin{array}{c}\text { Overall } \\
\mathrm{N}=116\end{array}$} & & & \\
\hline \multirow{7}{*}{$\begin{array}{l}\text { Dependent } \\
\text { Variable } \\
\text { (Self } \\
\text { leadership) }\end{array}$} & \multirow{3}{*}{$\begin{array}{l}\text { Leading Self- } \\
\text { behavior }\end{array}$} & $\begin{array}{c}\text { Goal } \\
\text { Setting }\end{array}$ & $\begin{array}{c}\mathrm{M} \\
\text { (SD) }\end{array}$ & & & & & & \\
\hline & & $\begin{array}{l}\text { Self- } \\
\text { observat } \\
\text { ion }\end{array}$ & $\begin{array}{c}\mathrm{M} \\
(\mathrm{SD})\end{array}$ & $\begin{array}{l}2.49 \\
(.65)\end{array}$ & $\begin{array}{l}3.80 \\
(.57)\end{array}$ & $\begin{array}{l}2.96 \\
(.89)\end{array}$ & 31.832 & $106.70^{* * *}$ & .490 \\
\hline & & Subtotal & $\begin{array}{c}\mathrm{M} \\
(\mathrm{SD})\end{array}$ & $\begin{array}{l}2.26 \\
(.60) \\
\end{array}$ & $\begin{array}{l}3.56 \\
(.58) \\
\end{array}$ & $\begin{array}{l}2.73 \\
(.87) \\
\end{array}$ & 30.308 & $127.63^{* * *}$ & .535 \\
\hline & \multirow{4}{*}{$\begin{array}{l}\text { Managing } \\
\text { Self- } \\
\text { thought }\end{array}$} & $\begin{array}{l}\text { Self- } \\
\text { awarene } \\
\text { ss }\end{array}$ & $\begin{array}{c}\mathrm{M} \\
(\mathrm{SD})\end{array}$ & $\begin{array}{l}2.54 \\
(.81)\end{array}$ & $\begin{array}{l}4.02 \\
(.65)\end{array}$ & $\begin{array}{c}3.07 \\
(1.04)\end{array}$ & 38.554 & $100.49 * * *$ & .475 \\
\hline & & $\begin{array}{l}\text { Imagina } \\
\text { tion of } \\
\text { Future } \\
\text { Success }\end{array}$ & $\begin{array}{c}\mathrm{M} \\
(\mathrm{SD})\end{array}$ & $\begin{array}{l}2.61 \\
(.68)\end{array}$ & $\begin{array}{l}3.83 \\
(.66)\end{array}$ & $\begin{array}{l}3.05 \\
(.89)\end{array}$ & 28.915 & $78.27 * * *$ & .414 \\
\hline & & $\begin{array}{c}\text { Self- } \\
\text { efficacy }\end{array}$ & $\begin{array}{c}\mathrm{M} \\
(\mathrm{SD})\end{array}$ & $\begin{array}{l}2.59 \\
(.56) \\
\end{array}$ & $\begin{array}{l}3.76 \\
(.58) \\
\end{array}$ & $\begin{array}{l}3.01 \\
(.79) \\
\end{array}$ & 25.112 & $131.21^{* * *}$ & .542 \\
\hline & & Subtotal & $\begin{array}{c}\mathrm{M} \\
\text { (SD) }\end{array}$ & $\begin{array}{l}2.58 \\
(.52) \\
\end{array}$ & $\begin{array}{l}3.86 \\
(.47) \\
\end{array}$ & $\begin{array}{l}3.04 \\
(.80) \\
\end{array}$ & 30.273 & $259.65^{* * *}$ & .701 \\
\hline \multicolumn{3}{|c|}{ Total } & $\begin{array}{c}\mathrm{M} \\
\text { (SD) }\end{array}$ & $\begin{array}{l}2.47 \\
(.51) \\
\end{array}$ & $\begin{array}{l}3.76 \\
(.46) \\
\end{array}$ & $\begin{array}{l}2.94 \\
(.80) \\
\end{array}$ & 30.284 & $258.07 * * *$ & 699 \\
\hline \multirow{3}{*}{$\begin{array}{l}\text { Dependent } \\
\text { Variable } \\
\text { (Super } \\
\text { leadership) }\end{array}$} & \multirow{3}{*}{$\begin{array}{l}\text { Driving } \\
\text { Action }\end{array}$} & $\begin{array}{c}\text { Communi } \\
\text { cation }\end{array}$ & $\begin{array}{c}\mathrm{M} \\
(\mathrm{SD}) \\
\end{array}$ & $\begin{array}{l}2.84 \\
(.55) \\
\end{array}$ & $\begin{array}{l}3.86 \\
(.61) \\
\end{array}$ & $\begin{array}{l}3.21 \\
(.75) \\
\end{array}$ & 18.680 & $73.224 * * *$ & .397 \\
\hline & & $\begin{array}{c}\text { Interperso } \\
\text { nal } \\
\text { Relations } \\
\text { hips } \\
\end{array}$ & $\begin{array}{c}\mathrm{M} \\
(\mathrm{SD})\end{array}$ & $\begin{array}{l}2.88 \\
(.47)\end{array}$ & $\begin{array}{l}4.09 \\
(.34)\end{array}$ & $\begin{array}{l}3.32 \\
(.72)\end{array}$ & 29.997 & $211.99 * * *$ & .656 \\
\hline & & $\begin{array}{c}\text { Motivatio } \\
\mathrm{n}\end{array}$ & $\begin{array}{c}\mathrm{M} \\
\text { (SD) }\end{array}$ & $\begin{array}{l}2.68 \\
(.58) \\
\end{array}$ & $\begin{array}{l}3.96 \\
(.47)\end{array}$ & $\begin{array}{l}3.14 \\
(.82) \\
\end{array}$ & 28.568 & $154.98 * * *$ & .583 \\
\hline
\end{tabular}




\begin{tabular}{|c|c|c|c|c|c|c|c|c|c|}
\hline & & Subtotal & $\begin{array}{c}\mathrm{M} \\
\text { (SD) }\end{array}$ & $\begin{array}{l}2.78 \\
(.42)\end{array}$ & $\begin{array}{l}3.96 \\
(.40)\end{array}$ & $\begin{array}{l}3.21 \\
(.70)\end{array}$ & 25.371 & $279.07 * * *$ & .715 \\
\hline & \multirow{3}{*}{$\begin{array}{l}\text { Inspiring } \\
\text { Challeng } \\
\mathrm{e}\end{array}$} & Insight & $\begin{array}{c}\mathrm{M} \\
\text { (SD) }\end{array}$ & $\begin{array}{l}2.33 \\
(.60)\end{array}$ & $\begin{array}{l}2.59 \\
(.46)\end{array}$ & $\begin{array}{l}2.43 \\
(.56)\end{array}$ & .327 & 1.50 & .013 \\
\hline & & $\begin{array}{c}\text { Pursuing } \\
\text { Excellenc } \\
\mathrm{e}\end{array}$ & $\begin{array}{c}\mathrm{M} \\
\text { (SD) }\end{array}$ & $\begin{array}{l}2.51 \\
(.71)\end{array}$ & $\begin{array}{l}2.80 \\
(.63)\end{array}$ & $\begin{array}{l}2.61 \\
(.69)\end{array}$ & .350 & 1.23 & .011 \\
\hline & & Subtotal & $\begin{array}{c}\mathrm{M} \\
\text { (SD) }\end{array}$ & $\begin{array}{l}2.39 \\
(.57)\end{array}$ & $\begin{array}{l}2.65 \\
(.45)\end{array}$ & $\begin{array}{l}2.48 \\
(.54)\end{array}$ & .334 & 1.97 & .018 \\
\hline \multicolumn{3}{|c|}{ Total } & $\begin{array}{c}\mathrm{M} \\
\text { (SD) }\end{array}$ & $\begin{array}{l}2.64 \\
(.44) \\
\end{array}$ & $\begin{array}{l}3.47 \\
(.38) \\
\end{array}$ & $\begin{array}{l}2.94 \\
(.58) \\
\end{array}$ & 11.519 & $135.04 * * *$ & .549 \\
\hline \multicolumn{3}{|c|}{ Multivariate Analysis Results } & \multicolumn{7}{|c|}{ Wilks lambda $=.145 \mathrm{~F}=60.35^{* * *} \eta^{2}=.855$} \\
\hline
\end{tabular}

$* \mathrm{p}<.05 * * \mathrm{p}<.01 * * * \mathrm{p}<.001$

\section{Discussions and Suggestions}

Leadership courses in universities these days are mostly taught as general education, and some universities, desiring their students to have greater opportunities to be educated in leadership, have made leadership courses to be requirements. According to the results of this study, if existing leadership courses and senior-junior mentoring activities are conjoined, self leadership and super leadership of university students could be improved more effectively. However, as there was no significant improvement of the super leadership sub factor 'inspiring challenge', there is a need to provide separate educational contents or activities for the detailed category of 'insight' within 'inspiring challenge'. There needs to be some research conducted on expanding and strengthening the relationship between senior-junior mentoring activities and leadership course and class content as a way to actively develop self and super leadership in university students, strategies for mentoring contents and methods, and lastly the senior factor of the seniors participating in mentoring.

\section{Acknowledgment}

Funding for this paper was provided by Namseoul University.

\section{References}

[1] S. Y. Lee, "How to improve the study circles in university?", Journal of Namseoul University, vol. 11, no. $1,(\mathbf{2 0 0 5})$, pp. 211-238.

[2] S. Y. Lee and Y. J. Hur, "Level of self leadership improvement based on senior-junior mentoring participation", 2015: Current Research Trend of Education V, Advanced Science and Technology Letters, ASTL, vol. 103, (2015), pp. 211-215.

[3] M. J. Kim, "An Inquiry into learner factors influencing the self-leadership development of university students", Doctoral Dissertation, Ewha Womans University, (2007).

[4] K. S. Lee and G. S. Kang, "A study on impact of self-leadership on civil organizational behavior, International Journal of Tourism and Hospitality Research", vol. 21, no. 1, (2007), pp. 241-261.

[5] H. S. Lee and M. E. Kwon, "Effect of empowerment on organizational effectiveness moderated by selfleadership", The Korean Journal of Human Resource Development, vol. 9, no. 2, (2007), pp. 1-18.

[6] J. S. Song and P. S. Yang, "A study on mediating effects of organizational commitment on the relationships between self-leadership and innovative behavior", Korean Corporation Management Review, vol. 26, (2008), pp. 189-209.

[7] T. H. Jung, "Effects of self leadership education on college students", The Journal of Korean Education, vol. 32, no. 1, (2005), pp. 223-248.

[8] C. C. Manz and H. P. Sims, "Leading workers to lead themselves: The external leadership of selfmanaging work teams", Administrative Science Quarterly, vol. 32, (1987), pp. 106-129.

[9] O. Brafman and R. A. Beckstrom, "The starfish and the spider: The unstoppable power of leaderless organizations", Penguin, (2006). 
[10] C. C. Manz and H. P. Sims, "Super leadership: beyond the myth of heroic leadership", Organizational Dynamics, vol. 19, no. 4, (1991), pp. 18-35.

[11] C. P. Neck and J. D. Houghton, "Two decades of self-leadership theory and research", Journal of Managerial Psychology, vol. 21, no. 4, (2006), pp. 270-295.

[12] C. C. Manz and H. P. Sims, "Super leadership. Leading others to lead themselves", New York: Prentice Hall, (1989).

[13] C. C. Manz and H. P. Sims, "Superleadership: beyond the myth of heroic leadership", Organizational Dynamics, vol. 19, no. 4, (1991), pp. 18-35.

[14] A. L. Kazen, "Exploring the concept of self-leadership: Factors impacting self-leadership of Ohio Americorps Members", Ph. D. diss., Graduate School of the Ohio State University, (2015).

[15] M. A. Kahn, "Self-leadership: Factors influencing self -managing activities of professionals in for-profit organizations", Ph. D. diss., Graduate School of the American University, (2015).

[16] A. Kim and B. S. Rhee, "An analytic study of identifying personal and institutional influences on the perceived development of core competencies of college students", The Journal of Korean Education, vol. 30, no. 1, (2003), pp. 367-392.

[17] M. J. Kim, "An inquiry into learner factors influencing the self-leadership development of university students", Ph. D. diss., Graduate School of the Ewha Womans University, (2007).

[18] Y. S. Noh and C. Y. Jyung, "Exploring the construct factors and developing the instrument for diagnosing the leadership of university students", Journal of Agricultural Education and Human Resource Development, vol. 46, no. 3, (2013), pp. 125-157.

\section{Authors}

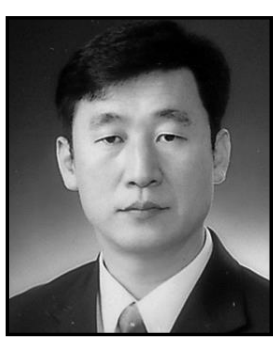

\section{Lee, Suk Yeol}

General Education, Namseoul University

91 Daehak-ro Seonghwan-eup Sebuk-gu Cheonan-si

Chungcheongnam-do S.KOREA

Major: Education Administration

Email: edupro@hanmail.net

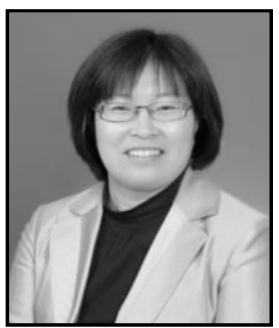

\section{Hur, Young Ju}

General Education, Namseoul University

91 Daehak-ro Seonghwan-eup Sebuk-gu Cheonan-si

Chungcheongnam-do S.KOREA

Major: Education Curriculum

Email: youngju@nsu.ac.kr 
International Journal of $u-$ and e- Service, Science and Technology Vol.8, No. 11 (2015) 